\title{
Remedies in asthma treatment: Introduce a new remedy from perspective of
}

\section{Persian medicine}

Majid Emtiazy ${ }^{1}$, Laleh Oveidzadeh ${ }^{*}$, Minoo Habibi² ${ }^{2}$ Zahra Jafari ${ }^{1}$, and Mohammad Kamalinejad ${ }^{3}$

1. Department of Persian Medicine, Faculty of Iranian Traditional Medicine, Shahid Sadoughi University of Medical Sciences, Ardakan, Yazd, Iran

2. Department of Internal medicine, Pulmonary ward, Labbafi Nezhad Hospital, Shahid Beheshti University of Medical Sciences, Tehran, Iran

3. Department of Pharmaceutics, Faculty of Pharmacy, Shahid Beheshti University of Medical Sciences,

\section{Tehran, Iran}

\section{RESEARCH}

Please cite this paper as: Emtiazi M, Oveidzadeh L, Habibi M, Jafari Z, Kamalinejad M. Remedies in asthma treatment: Introduce a new remedy from perspective of Persian medicine. AMJ 2018;11(1):6-13.

https://doi.org/10.21767/AMJ.2017.3245

\section{Corresponding Author:}

Laleh Oveidzadeh

Department of Persian Medicine

Faculty of Iranian Traditional Medicine

Shahid Sadoughi University of Medical Sciences

Ardakan, Yazd, Iran

Email: I_oveidzadeh@yahoo.com

\section{ABSTRACT}

\section{Background}

Asthma is a chronic inflammatory disease of the airways. Mucus plug formation, oxidative stress, swelling of the airway walls, inflammatory process and vascular changes are important events in asthma pathogenesis.

\section{Aims}

Although bronchodilators and steroids are two main drugs in asthma treatment, many adults and children still use complementary and alternative (CAM) medicine. This study was conducted to determine the most popular remedies in asthma treatment from perspective of Traditional Persian medicine (TPM) manuscripts.

\section{Methods}

The main Traditional Persian textbooks from the 9th to 18th centuries AD were collected and analysed. Thereafter, the most listed plants in asthma treatment were gathered. The plants in this list were searched and compared in recent studies.

Results

Some of these plants have anti- inflammatory and antioxidant effects; a few of them have undergone animal or human researches in conventional medicine.

\section{Conclusion}

According to long history of medicine in Persia the collected list of remedies could be helpful in selecting plants for future studies in asthma treatment.

\section{Key Words}

Asthma, traditional Persian medicine, Trigonella graecum L., antioxidant, complementary and alternative medicine, fenugreek

\section{What this study adds:}

\section{What is known about this subject?}

Although bronchodilators and steroids are two main drugs in asthma treatment, many adults and children still use complementary and alternative (CAM) medicine.

\section{What new information is offered in this study?}

Based on TPM and recent studies, some remedies were determined to have useful effects in asthma treatment. One of the special remedies in asthma treatment from the TPM point of view is Trigonella graecum L.

3. What are the implications for research, policy, or practice?

According to long history of medicine in Persia the collected list of remedies could be helpful in selecting plants for future studies in asthma treatment. 


\section{Background}

One of the famous pulmonary diseases is Asthma that characterized by airway hyper-responsiveness, airflow restriction, acute broncho-constriction, swelling of the airway walls, chronic mucus plug formation and airway wall remodelling. ${ }^{1}$ Oxidative stress has been indicated as the main related mechanisms of asthma disease. ${ }^{2}$ It is mentioned to be the most important event in inflammatory process. ${ }^{3}$ Increased oxidative stress is related to the severity of asthma. ${ }^{4}$ In animal research studies, $\mathrm{H} 2 \mathrm{O} 2$ caused contraction of airway's smooth muscle and hyper responsiveness. ${ }^{5}$ Asthma as a major chronic respiratory disease has a prevalence of about 300 million in adults and children all over the world. In USA statistics show 15.7 million adults and 6.5 million children are suffering from asthma symptoms. ${ }^{1}$ In westernized countries, asthma prevalence has increased to $50 \%$ in the past few decades. Although, recent anti- asthmatic drugs are effective in asthma treatment, there is still no cure for asthma. Drugs side effects in chronic usage are another concern especially in children. Non-adherence to medical regimens has been estimated to cost $\$ 100$ billion annually for health-care system in the United States. Hence, the result of this nonadherence could be the loss of chances for patients to amend their health and also loss of medication by healthcare providers which results in increased morbidity. ${ }^{6}$ Because of the chronicity of asthma and lack of preventive principles and curative treatment the patients use complementary and alternative medicine (CAM) treatment, especially in western countries. ${ }^{7,8}$ It seems that up to $30 \%$ of adults and $60 \%$ of children in the US still use some form of CAM for asthma treatment. ${ }^{9}$ The Traditional Persian medicine (TPM) system is one of the ancient systems of CAM in the world. Although, more studies are required to find useful remedies with lesser side effects for asthma management; some remedies from Persian Traditional medicine textbooks could be recommended. Since medication prescriptions from TPM were used by ancient physicians and people over the years, it is very likely that these remedies will be selected for future studies. The aim of this study is to find a new hope with lesser side effects and better adherence in asthma treatment.

\section{Method}

The treatment principles of asthma and the remedies that have been used were collected and analysed from Persian Traditional Medicine (PTM) manuscripts. From 9th to 18th centuries AD, like Al- Mansuri- Fi- Teb(9th and 10th centuries), Canon of medicine(11th century), Mofarah- AlGholoub(18th century) and Exir- e- Azam(19th century), as well as some pharmaceutical books like Makhzan- AlAdvieh, Alshamel and Moalejat - e-Aghili were collected and analysed. According to these analyses, a list of more frequent remedies was prepared. Up to September, 2017, electronic databases including Pub Med, Scopus, Web of Science, Google Scholar, and the Cochrane library were searched with scientific names of plants separately. English and Persian language publications were included. Some mentioned remedies had been proved in animal or human studies on asthma. 13,14,23-25,29,32,41 Studies that exhibited apparent efficacy or indirect effectiveness on asthma pathogenesis were selected for this current research. Duplication was avoided by excluding multiple copies of the same article in different databases. The key words are the scientific name and common name of the plants in the whole text and the terms "asthma" or "flavonoid" or "antioxidant" or "anti-inflammation" in the title and abstract.

\section{Results}

Table 1: shows the remedies based on TPM manuscripts and their consumption instruction. Their efficacy in asthma treatment was compared with new studies.

\section{Discussion}

Treatment in TPM is based on humors theory. ${ }^{59}$ From perspective of Persian Medicine the most common pathology for asthma disease is air way restriction and mucus formation due to phlegm [60-62]. So they consider plants which can clean and wash out this excessive phlegm.

As shown in Table 1 Many of these remedies are antioxidant and have anti- inflammatory effects like Honey, Pistacia terebinthus, Linum Usitatissimum, Ficus Carica [Table 1] some of them don't have any investigations in conventional medicine but a few of them have clinical trials like Glycyhiza glabra, Boswella sacra, Drimia maritime and Nigella sativa. ${ }^{13,14,23-25,29,32,41}$ Despite of the positive results, more studies with larger sample size and stronger study designs are recommended.

Through these remedies with regard to Persian scholars' point of view we selected the Trigonella foenum graecum for our future research. T. foenum- graecumL has the common name; Fenugreek which belongs to the family Leguminosae. All articles that made mention of this plant in their abstract and entire paper work were selected and analysed.

Fenugreek is an annual plant. This plant is used alone or in combination for relieving asthma symptoms in many TPM prescriptions. ${ }^{60-62}$ Fenugreek seeds have been known as a 
spice from ancient time and also had some medical uses, for example, appetizer, tonic, carminative, expectorant and etc. ${ }^{60-62}$ In "Makhzanal- advieh" one of the famous Persian Traditional pharmacology books $T$. foenum- graecum $\mathrm{L}$. (Fenugreek) was stated as the lung tonic. ${ }^{63}$ In recent researches, fenugreek seeds were observed to have antidiabetic, $^{64-66}$ hypocholesterolaemic effects ${ }^{67}$ and antioxidant properties. Also there is report that $T$. foenumgraecum L. could have anti- peptic ulcer actions. ${ }^{68}$ Antibacterial, anti-worm effects, ${ }^{69}$ immunomodulatory ${ }^{66,70}$ and anti-inflammatory effects are other features of $T$. foenumgraecum L.

\section{Chemical analysis of fenugreek seeds}

- Alkaloides: ${ }^{71}$ Trimethylamine, Neurin, Trigonelline, Choline, Gentianine, Carpaine and Betain. Saponins: ${ }^{72}$ Graecunins, fenugrin B, fenugreekine and trigofoenosides A-G.

- Steroidal sapinogens: Yamogenin, diosgenin, smilagenin, sarsasapogenin, tigogenin, neotigogenin, gitogenin, neogitogenin, yuccagenin and saponaretin. - Fibers: Gum, neutral detergent and fiber. ${ }^{73}$

- Flavonoids: Orientin, Vitexin and Quercetin. ${ }^{74,75}$

- Amino acids: Isoleucine, 4-Hydroxyisoleucine, Histidine, Leucine, lysine, L-tryptophan and Arginine.

Other: Coumarin, lipids, vitamins, minerals. Mucilage (28\%) and Proteins (22\%).

\section{Active ingredient helpful in asthma management}

Many epidemiologic studies have reported beneficial effects of flavonoids on asthma. ${ }^{76}$ Poly phenols are the most important low molecular weight of Flavonoids. ${ }^{77,78}$ Besides the anti-oxidative effects; flavonoids can inhibit the activation of basophiles and mast cells and thus prevent histamine and other preformed granule-associated mediators release that lead to granule- associated process. $^{79}$ One of the well-known flavonoids that inhibits the eosinophilic secretion of Charcot-Leyden crystal protein and eosinophil cationic protein is Quercetin. ${ }^{80}$ Another major part of asthma pathogenesis is vascular changes. ${ }^{81}$ These changes consist of an increase in vascular permeability, vascular dilation, and vasculogenesis which is called angiogenesis. ${ }^{81}$ It has been shown that flavonoids and their certain compounds have demonstrated the ability to modulate the expression of HIF-1, VEGF, matrix metalloproteinase (MMPs), and epidermal growth factor receptor and also inhibit NF-KB, PI3K/Akt, and ERK1/2 signalling pathways. ${ }^{82,83}$ Finding a drug which could balance between TH1/TH2 and avoid the inflammation and angiogenesis process and mucus formation, would be a major success in asthma treatment. As mentioned in the results, fenugreek seeds have anti-inflammatory effects and possess acceptable flavonoids content. $T$. foenum- graecum L. showed anti- oxidant effects which could explain the antiinflammatory activities by regulation of various inflammatory mediators that could have protective vascular effects. Saponins and flavonoids are two major compounds of fenugreek that can approximately explain the antiinflammatory activity of this plant. ${ }^{84}$ Despite these positive data on Fenugreek usage in asthmatic patients, there are still some conflicting findings of Fenugreek in some reports. Patients who have allergy to Fenugreek or chickpeas must take caution in using this herb, because of the possible reactions. ${ }^{85}$ Studies have reported some side effects such as transient diarrhoea and distension ${ }^{86}$ also dizziness. ${ }^{87}$ Another theoretical risk is increase in prothrombin time (PT) or the international normalized ratio (INR), that could lead to increase bleeding risk. ${ }^{88}$ In early animal researches, Fenugreek has the potential of stimulating the uterine, hence it should be avoided during pregnancy. ${ }^{89}$

\section{Conclusion}

This study revealed some remedies that could be useful in asthma treatment from Traditional Persian Medicine (TPM) perspective. From the selected remedies, Trigonella graecum L. was widely searched. According to these findings one small randomized controlled trial is designed in Shahid Sadoughi School of Persian medicine in Yazd to compare the effect of Fenugreek seeds with placebo. Its results will be published as soon as the work is completed, but more studies in large trials which are designed for randomized controlled with placebo are still needed to observe the effectiveness of Fenugreek in asthma treatment cautiously.

\section{References}

1. CDC. National Center for Health Statistics: Asthma. [Accessed March 14, 2007.]. http://wwwcdcgov/nchs/fastats/asthmahtm

2. Park HS, Kim SR, Lee YC. Impact of oxidative stress on lung diseases. Respirology. 2009;14:27-38.

3. Dworski R. Oxidant stress in asthma. Thorax. 2000;55:S51-S53.

4. Barnes PJ. Reactive oxygen species in asthma. Eur Respir Rev. 2000;10:240-243.

5. Lee KS, Kim SR, Park SJ, et al. Hydrogen peroxide induces vascular permeability via regulation of vascular endothelial growth factor. Am J Respir Cell Mol Biol. 2006;35:190-197.

6. Horne R. Concordance and medicines management in the respiratory arena. 2003; Harward Medical Publications. London, UK. 
7. Hassed C. An integrative approach to asthma. Aust Fam Physician. 2005;34(7):573-6. [PubMed:15999168].

8. Bielory L, Russin J, Zuckerman GB. Clinical efficacy, mechanisms of action, and adverse effects of complementary and alternative medicine therapies for asthma. Allergy Asthma Proc. 2004;25(5):283-91. [PubMed: 15603200].

9. Slader CA, Reddel HK, Jenkins CR, et al. Complementary and alternative medicine use in asthma: who is using what? Respirology. 2006;11(4):373-87. [PubMed:16771907].

10. Alvarez-Suarez JM, Tulipani S, Romandini S, et al. Contribution of honey in nutrition and human health; a review. Mediterr J Nutr Metab. 2010;3:15-23.

11. Al-Mamary M, Al-Meeri A, Al-Habori M. Anti-oxidant activities and total phenolitics of different types of honey. Nutr Res. 2002;22:1041-1047.

12. Estevinho L, Pereira AP, Moreiral G, et al. Antioxidant and antimicrobial effects of phenolic compounds extracts of northeast Portugal honey. Food Chem Toxical. 2008;46:3774-37779.

13. Al-Jawad FH, Al-Razzugi RA, Hashim HM, et al. Glycyrrhiza glabra versus Boswellia carterii in chronic bronchial asthma; A comparative study of efficacy. Indian Journal of Allergy, Asthma and Immunology. 2012;26(1):6.

14. Wen MC, Wei Ch, Hu ZQ, et al. Efficacy and tolerability of anti asmathic herbal medicine intervention in adult patients with modrate- severe allergic asthma. J Allergy Clin Immunol. 2005;116 (3):517-24.

15. Mandalari G, Bisignano C, Genovese T, et al. Natural almond skin reduced oxidative stress and inflammation in an experimental model of inflammatory bowel disease. Int Immun Pharm. 2011;11:915-924. doi:10.1016/j.intimp. 2011.02.003.

16. Berryman CE, Preston AG, Karmally W, et al. Effects of almond consumption on the reduction of LDLCholestrol: a discussion of potential mechanisms and future research directions. Nutr Rev. 2011;69:171-185.

17. Fan S, Hu Y, Li C, et al. Optimization of preparation of antioxidative peptides from pumkin seeds using response surface method. PloS One. 2014;9(3):e92335.

18. Kavak DD, Altiok E, Bayraktar O, et al. Pistacia terebinthus extract: as a potential antioxidant, antimicrobial and possible B- glucuronidase inhibitor. J Mol Catal B. 2010;64(3-4):167-171.

19. Giner-Larza EM, Manez S, Giner RM, et al. Antiinflammatory triterpenes from Pistacia terebinthus galls. Planta Medica. 2002;68(4):311-315.

20. Abdel-Tawab M, Werz O, Schubert-Zsilavecz $M$. Boswellia Serrata: an overall assessment of in vitro, preclinical, pharmaco- kinetic and clinical data. Clin Pharmacokinet. 2011;50:349-369.

21. Al-Jawad FH, Al-Razzugi RA, Hashim $H M$, et al. Glycyrrhiza glabra versus Boswellia carterii in chronic bronchial asthma; A comparative study of efficacy. Indian Journal of allergy. Asthma and Immunology. 2012;26(1):6.

22. Gupta I, Gupta V, Parihar A, et al. Effects of Boswellia Serrata gum resin in patients with bronchial asthma: results of double- blind, placebo controlled, 6- week clinical study. Eur J Res. 1998;3:511-514.

23. Nejatbakhsh F, Kargar-Borzi H, Amin Gh, et al. Squill oxymel, a traditional formulation from Drimia Maritima stearn, as an add- on treatment in patients with modrate to severe persistent asthma: A pilot, tripleblind, randomized clinical trial. J Ethnopharmacol. 2017;196:186-192.

24. Bashir S, Abbas S, Khan A, et al. Studies on bronchodilator and cardiac stimulant activities of Urginea indica. Bangladesh J Pharmacol. 2013;8,249254.

25. Kargar-Borzi H, Salehi M, Rahimi R. Lauq: A sustainedrelease dosage form for respiratory disorders in traditional Persian medicine. J Evid Based Complementary Altern Med. 2016;21(1):63-70.

26. Bouaziz F, Koubaa M, Barba JF, et al. Antioxidant properties of water- soluble gum from flaxseed hulls. Antioxidants (Basel). 2016;5(3):26. doi: 10.3390/antioxiant5030026.

27. Karamac M, Kosinska-Cgnazzo A, Kulczyk A. Use of different proteases to obtain flaxseed protein hydrolysis with antioxidant activity. Int J Mol Sci. 2016;17(7):1027. doi.10.3390/ ijms17071027.

28. Yang G, Min S, Hong S. Therapeutic effects of fermented flax seed oil on NC/Ng mice with atopic dermatitis- like skin lesions. J Evid Based Complement Altern Med. 2017;2017:5469125. doi:10/1155/2017/5469125.

29. Koshak A, Wei L, Koshak E, et al. Nigella sativa supplementation improves asthma control and biomarkers: A Randomized, double blind, placebocontrolled trial. Phytother Res. 2017;31(3):403-9.

30. Abdol-Aziz M, Abass A, Zalata K, et al. Effect of dexamethasone and Nigella sativa on inducible nitric oxide synthase in the lungs of marine model of allergic asthma. Iranian Journal of Allergy, Asthma and Immunology. 2014;13(5):324.

31. Shrimali D, Shanmugam MK, Zhang J, et al. Targeted abrogation of diverse signal transduction cascades and cancer. Cancer Lett. 2013;341(2):139-49.

32. Chu X, Wei M, Yang $X$, et al. Effects of anthraquinone derivative from Rheum officinale Baill, emodin, on 
airway responses in murine model of asthma. Food Chem Toxicol. 2012;50(7):2368-75.

33. Jeong MR, Kim HY, Cha JD. Antimicrobial activity of methanol extract from Ficus Carica leaves against oral bacteria. J Bacteriol Virol. 2009;39(2):97-102.

34. Vinson JA, Zubik L, Bose $P$, et al. Dried fruits: excellent in vitro and invivo antioxidants. J Am Coll Nutr. 2005;24(1):44-50.

35. Caliskan O, Polat AA. Phytochemical and antioxidant properties of selected fig (Ficus Carica L.) accessions from the eastern Mediterranean region of turkey. Scientia Horticulturae. 2011;128(4):473-478.

36. Chang SC, Hsu BY, Chen BH. Structural characterization of poly saccharides from Ziziphus Jujuba and evaluation of antioxidant activity. Int J Biol Macromol. 2010;47(4):445-453.

37. Xu YL. Miao M-S, Sun Y-H, et al. Effect of fructose Jujubae poly saccharide on the hematopoietic function in mice model of both qi and blood deficiencies. Chinese Journal of Clinical Rehabilitation. 2004;8(24):5050-5051.

38. Zhao Z, Liu M, Tu P. Characterization of water soluble poly saccharides from organs of Chinese Jujube (Ziziphus Jujuba Mill. cv. Dongzao) European Food Research and Technology. 2008;226(5):985-989.

39. Gdula-Arqasinska J, Pasko P, Sulkowska-Ziaja K, et al. Anti-inflammatory activities of garlic sprouts, a source of alfa- linolenic acid and 5-hydroxyl-L-Tryptophan, in RAW264.7 cells. Acta Biochem Pol. 2017;64(3):551-559.

40. Lu X, Li N, Qiao X, et al. Composition analysis and antioxidant properties of black garlic extract. 2017;25(2):340-349.

41. Islam MN, Yadav RL, Yadav PK. Modulation of lung function by increased nitric oxide production. J Clin Diagn Res. 2017;11(6):cc09-cc12.

42. Ma X, Ma X, Ma Z, et al. Effect of Hyssopus officinalis L. on inhibiting airway inflammation and immune regulation in a chronic asthmatic mouse model. Exp Ther Med. 2014;8(5):1371-1374.

43. Hou M, Ma X, Ding J, et al. Effect of Uygur medicine Hyssopus Officinalis L. on serum eotaxin-2, eotaxin-3 and sp- selectin level of asthma rats. Science and Technology Review. 2009;28(19):90-93.

44. Wang HY, Ding JB, Halmurat U, et al. The effect of Uygur medicine Hyssopus Officinalis L. on expression of T-bet, GATA-3 and STAT-3 mRNA in lung tissue of asthma rats. Xi Bao Yu Fen Zi Mian Yi Xue Za Zhi. 2011;27(8):876-879.

45. Yanan W, Jun $M$, Xiumin $M$, et al. Effects of Uygur herb Hyssopus officinalis L. on cytokines in allergic asthma mice. Acta Universitotis Traditionis Medicalis Sinensis Pharmacologi aeque Shanghai. 2008;22(3):58-60.
46. Gupta V, Bansal P, Kumar P. Anti-inflammatory and antinociceptive activity of Adiantum capillus. Res J Pharm Tech. 2010;3:432-434.

47. Kumar A. Anti-oxidant effect of Adiantum capillus veneris Linn. On human lymphocyte: An invitro study. J Cell Tissue Res. 2009;9:1899-1902.

48. Biswos SK, Chowdhury A, Das J, et al. Phytochemical investigation and chromatographic evaluation with antimicrobial and cytotoxic potential of Cuscuta Epithymum. Int J Pharm. 2012;8:422-27.

49. Research updates Dodder seed.2003. http://www.mdidea.com

50. Rahimi R, Ardakani MR. Medicinal properties of Foeniculum Vulgaris Mill. In traditional Iranian Medicine and modern phytotherapy. Chin J Integr Med. 2013;19:73-79.

51. Miguel MG, Cruz C, Faleiro L, et al. Foeniculum vulgare essential oils: Chemical composition antioxidant and antimicrobial activities. Nat Prod Commun. 2010;5(2):319-28.

52. Nassar MI, Aboutabl EA, Makled YA, et al. Secondary metabolites and pharmacology of Foeniculum vulgare Mill. Subsp. Piperitum. Revista Latinoamericana de Quimica. 2010;38(2):103-112.

53. Siddiqi HS, Mehmood MH, Rehman NU, et al. Studies on the antihypertensive and antidyslipidemic activities af Viola Odorata leaves extract. Lipids Health Dis. 2012;11:6.

54. Ebrahimzadeh MA, Nabavi SM, Nabavi SF, et al. Antioxidant and free radical scavenging activity of $H$. officinalis L. var. angustifolius, V. odorata, B. hyrcana and C. speciosum. Pak J Pharm Sci. 2010;23(1): 29-34.

55. Koochek MH, Pipelzadeh $\mathrm{MH}$, Mardani $H$. The effectiveness of Viola odorata in: the prevention and treatment of formalin- induced lung damage in the rat. J Herbs Spices Med Plants. 2003;10:95-103.

56. Qasemzadeh MJ, Sharifi H, Hamedanian M, et al. The effect of viola odorata flower syrup on the cough of children with asthma: a double- blind, randomized controlled trial. J Evid Based Complementary Altern Med. 2015;20(4):287-291.

57. El-Sokkary AM, Ghoneim MA. Effect of plants antioxidants in retarding the oxidative deterioration of Samna [Ghee]. Indian J Dairy Sci. 1951;4:123-8.

58. Ahmadiani A, Javan M, Semnanian S, et al. Antiinflammatory and antipyretice effects of Trigonella foenum-graecum leaves extract in the rat. J Ethnopharmacol. 2001;75:283-286.

59. Mojahedi M, Naseri M, Mojdzadeh R, et al. Reliability and validity assessment of Mezaj questionnaire: A novel 
self- report scale in Iranian Traditional Medicine. Iran Red Crescent Med J. 2014;16(3):e15924.

60. Aviecinna. Kitab al- Qanun Fi al- tibb (Canon of Medicine Tehran). Volo2: Soroosh Press; 1988.

61. Shah- Arzani MA. Tibb - e- Akbari (Akbar's Medicine). Qom: Jalal- ed- Din; 2008.

62. Razee, Z. Kitab al- Havi Fi al- tibb. Volo4: Heidarabad Dakkan. 1957;1-36.

63. Alavi Khorasani, MH. Makhzan al- advieh. Tehran University. 2012;334-35.

64. Thakran S, Siddiqui MR, Baquer NZ. Trigonella foenumgraecum seed powder protects against histopathological abnormalities in tissues of diabetic rats. Mol Cell Biochem. 2004;266(1):151-159.

65. Kumar SG, Shetty AK, Sambaiah K, et al. Anti-diabetic property of fenugreek seed mucilage and spent turmeric in streptozotocin-induced diabetic rats. Nutr Res. 2005;25(11):1021-1028.

66. Baquer NZ, Kumar P, Taha A, et al. Metabolic and molecular action of Trigonella foenum-graecum (fenugreek) and trace metals in experimental diabetic tissues. J Biosci. 2011;36(2):383-96.

67. Abdel-Barry JA, Abdel-Hassan IA, Al-Hakiem MHH. Hypoglycaemic and antihyerglycaemic effects of Trigonella foenum-graecum leaf innormaland alloxan induceddiabeticrats. J Ethnopharmacol. 1997;58(3):149155.

68. Pandian RS, Anuradha CV, Viswanathan P. Gastroprotective effect of fenugreek seeds (Trigonella foenum -graecum) on experimentalgastric ulcer in rats. J Ethnopharmacol. 2002;81(3):393-7.

69. Sudar O, Kirti PB. Cloning, characterization and antifungal activity of defensin $\mathrm{T}$ fgd1 from Trigonella foenum-graecum L. J Biochem Mol Biol. 2006;39(3):278283.

70. Ramesh HP, Yamaki K, Tsushida T. Effect of fenugreek galactomannan fractions on phagocytosis in rat macrophages and proliferation and IgM secretion in HB4C5 c ells. Carbohyd Polym. 2002;50:79-83.

71. Jain SC, Madhu A. Regulation of Trigonella species by chemical mutagenic treatments. Indian Drugs. 1988;26(1):14-18.

72. Basch E, Ulbricht C, Kuo G, et al. Trapeutic applications of fenugreek. Altern Med Rev. 2003;8(1):20-27.

73. Hannan JM, Ali L, Rokeya, et al. Soluble dietary fibre fraction of Trigonella foenum-graecum (fenugreek) seed improves glucose homeostasis in animal models of type 1 and type 2 diabetes by delaying carbohydrate digestion and absorption, and enhancing insulin action. Br J Nutr. 2007;97(3):514-21.
74. Skibola CF, Smith MT. Potential health impacts of excessive flavonoid intake. Free Radical Biol Med. 2000;29(3):375-383.

75. Petit PR, Sauviaire YD, Hillaire-Buys DM, et al. Steroid saponins from fenugreek seeds: extraction, purification and pharmacological investigation on feeding behavior and plasma cholesterol. Steroids. 1995;60(10):674-680.

76. Shaheen SO, Sterne JA, Thompson RL, et al. Dietary antioxidants and asthma in adults: population-based case-control study. Am J Respir Crit Care Med. 2001;164(10):1823-1828.

77. Balsano C, Alisi A. Antioxidant effects of natural bioactive compounds. Curr Pharmaceu Des. 2009;15(26):3063-3073.

78. Williams CA, Grayer RJ. Anthocyanins and other flavonoids. Nat Prod Rep. 2004;21(4):539-573.

79. Ogasawara $H$, Fujitani $T$, Middleton $E$, et al. The role of hydrogen peroxide in basophile histamine release and the effect of selected flavonoids. J Allergy Clin Immunol. 1986;78(2):321-328.

80. Sloan R, Boran-Ragotzy R, Ackerman SJ, et al. The effect of plant flavonoids on eosinophil degranulation. J Allergy Clin Immunol. 1991;87(1):282.

81. Park HS, Kim SY, Kim SR, et al. Targeting abnormal airway vasculatiry as a therapeutical strategy in asthma. Respirology. 2010;15(3):459-471.

82. Mojzis J, Varinska L, Mojzisova, et al. Antiangiogenic effects of flavonoids and chalcones. Pharmacol Res. 2008;57(4):259-265.

83. Oak MH, El Bedoui J, Schini-Kerth VB. Antiangiogenic properties of natural polyphenols from red wine and green tea. J Nutr Biochem. 2005;16(1):1-8.

84. Sharififar F, Khazaeli P, Alli N. In vivo evaluation of antiinflammatory activity of topical preparations from fenugreek (Trigonella foenum-graecum L.) seeds in a cream base. Iran J Pharm Sci. 2009;5(3):157-162.

85. Patil SP, Niphadkar PV, Bapat MM. Allergy to fenugreek (Trigonella foenum-graecum). Ann Allergy Asthma Immunol. 1997;78(3):297-300.

86. Sharma RD, Sarkar A, Hazra DK, et al. Toxicological evaluation of fenugreek seeds: along term feeding experiment in diabetic patients. Phytother Res. 1996;10:519-520.

87. Abdel-Barry JA, Abdel-Hassan IA, Jawad AM, et al. Hypoglycemic effect of aqueous extract of the leaves of Trigonella foenum-graecum in healthy volunteers. East Mediterr Health J. 2000;6:83-88.

88. Lambert JP, Cormier A. Potential interaction between warfarin and boldo-fenugreek. Pharmacotherapy. 2001;21:509-512. 
89. Abdo MS, al-Kafawi AA. Experimental studies on the effect of Trigonella foenum-graecum. Planta Med. 1969;17:14-18.

\section{ACKNOWLEDGEMENTS}

There is no acknowledgement of this paper

\section{PEER REVIEW}

Not commissioned. Externally peer reviewed.

\section{CONFLICTS OF INTEREST}

The authors declare that they have no competing interests.

\section{FUNDING}

None

\section{ETHICS COMMITTEE APPROVAL}

Not needed 
Table1: Remedies in asthma treatment from perspective of Persian Traditional Medicine

\begin{tabular}{|c|c|c|c|}
\hline $\begin{array}{l}\text { Common name } \\
\text { in TPM }\end{array}$ & Scientific name & $\begin{array}{l}\text { The used } \\
\text { part }\end{array}$ & Uses in conventional medicine \\
\hline Assal & Honey & $\begin{array}{l}\text { The hole } \\
\text { liquid }\end{array}$ & $\begin{array}{ll}- & \text { Antioxidant }^{10,11} \\
- & \text { Anti-inflammatory }\end{array}$ \\
\hline $\begin{array}{l}\text { Shirin bian } \\
\text { (soos) }\end{array}$ & Glycyhiza glabra & Rhizome & $\begin{array}{ll}- & \text { Increase inFEV1 levels } \\
\text { - } & \text { In ASHMA combination improve the lung function test and reduce the interlokin } \\
\text { levels }^{14}\end{array}$ \\
\hline $\begin{array}{l}\text { Badam shirin } \\
\text { (Looz al- holve) }\end{array}$ & Prunus dulcin & Fruit & $\begin{array}{ll}\text { - } & \text { Contains polyphenols and has antioxidant activity } \\
\text { - } & \text { Almond has high levels of monounsaturated fat }\end{array}$ \\
\hline Kadoo (gharee) & Cucurbita pepo L. & $\begin{array}{l}\text { Fruit and } \\
\text { Seeds }\end{array}$ & Antioxidant $^{17}$ \\
\hline Saghez & $\begin{array}{l}\text { Pistacia } \\
\text { terebinthus }\end{array}$ & Gum & Antioxidant $^{18}$ and anti-inflammatory effects ${ }^{19}$ \\
\hline Kondor & Boswellia sacra & Gum & $\begin{array}{ll}- & \text { Anti-inflammatory } \\
\text { - } & \text { Improve the spirometery parameters } \\
21,22\end{array}$ \\
\hline Squill & Drimia Maritima & Vinegar & $\begin{array}{ll} & \text { Significantly improved spirometery parameters } \\
\text { - } & \text { Reduction mucus secretion of the airway } \\
\text { - } & \text { Useful in respiratory diseases including asthma } \\
& \end{array}$ \\
\hline Katan & $\begin{array}{l}\text { Linum } \\
\text { Usitatissimum }\end{array}$ & Seeds & $\begin{array}{l}\text { - } \quad \text { Antioxidant effects }{ }^{26,27} \\
\text { - } \quad \text { Using flaxseed oil reduce IL4 cells in layer near the base of epithelium in atopic } \\
\text { dermatitis patients }{ }^{28}\end{array}$ \\
\hline $\begin{array}{l}\text { Siah Daneh } \\
\text { (Shooniz) }\end{array}$ & Nigella Sativa & Seeds & $\begin{array}{l}\text { - Nigella oil reduces eosinophilia and improves quality of life in asthma patients } \\
\text { Anti-inflammatory and immunomedulatory effect on marine lung tissue }\end{array}$ \\
\hline Chinese Ravand & Rheum Officinale & $\begin{array}{l}\text { Root and } \\
\text { Bark }\end{array}$ & $\begin{array}{ll}\text { - } & \text { Emodin isolated from barks and root has anti-inflammatory and antibacterial effects } \\
\text { - } & \text { Emodin could delay airway inflammation process on non-infection asthma in mouses }\end{array}$ \\
\hline Anjir (Tin) & Ficus Carica & Fruit & $\begin{array}{ll}\text { - } & \text { Antiinflammatory effects } \\
\text { - } & \text { Ficus is rich in polyphenoles and works as a strong antioxidant } \\
& 34,35\end{array}$ \\
\hline Onnab & Ziziphus Jujuba & Fruit & $\begin{array}{ll}- & \text { Antioxidant effects } \\
\text { - } & \text { Immune-modulating effects } \\
37,38\end{array}$ \\
\hline Sir (Soom) & Allium Sativum & Cloves & $\begin{array}{l}\text { - } \quad \text { Anti-inflammatory }{ }^{39} \text { and antioxidant }{ }^{39,40} \\
\text { - } \quad \text { Using } 4 \text { gr raw garlic per day in asthmatic smokers show significant increase in } \\
\text { spirometery parameters }{ }^{41}\end{array}$ \\
\hline Zoofa & $\begin{array}{l}\text { Hyssopus } \\
\text { Officinalis }\end{array}$ & Flower & $\begin{array}{ll}\text { - } & \text { Anti-inflammatory effects and reduction of IgE levels } \\
\text { - } & \text { Reduce the level of IL4, IL6, IL17 }\end{array}$ \\
\hline Parsiavoshan & $\begin{array}{l}\text { Adiantum Capilus } \\
\text { Veneris }\end{array}$ & Leaf & Antioxidant and anti-inflammatory effects ${ }^{46,47}$ \\
\hline Aftimoon & $\begin{array}{l}\text { Cuscuta } \\
\text { Epithymum }\end{array}$ & $\begin{array}{l}\text { Aerial } \\
\text { parts }\end{array}$ & $\begin{array}{ll}- & \text { Anti-microbial effects } \\
\text { - } & \text { Contains flavonoids which can act as antioxidants } \\
\end{array}$ \\
\hline Razianaj & $\begin{array}{l}\text { Foeniculum } \\
\text { Vulgare Mill. }\end{array}$ & Seeds & $\begin{array}{ll}\text { - } & \text { Seeds contain flavonoids that are considers as important antioxidants } \\
\text { - } & \text { Anti-inflammatory activity }\end{array}$ \\
\hline Banafsej & Viola Odorata L. & Flower & $\begin{array}{ll}- & \text { Antimicrobial } \text { effect }^{53} \\
\text { - } & \text { Antioxidant } \\
\text { - } & \text { Lung tissue protection } \\
\text { - } & \text { Effective in controlling of cough among children with asthma }\end{array}$ \\
\hline $\begin{array}{l}\text { Shanballileh } \\
\text { (Holbeh) }\end{array}$ & $\begin{array}{l}\text { Trigonella Foenum } \\
\text { Graecum L. }\end{array}$ & Seeds & $\begin{array}{ll}- & \text { Antioxidant }^{57} \\
\text { - } & \text { Anti-inflammatory effects }{ }^{58} \text { seeds contain } 28 \% \text { mucilage }\end{array}$ \\
\hline
\end{tabular}

